\title{
Temperature and Scarification Effects on Germination of Prostrate Bundleflower Seeds
}

\author{
TIMOTHY E. FULBRIGHT AND KAY S. FLENNIKEN
}

\begin{abstract}
A hard seed cont restricts germination of prostrate bundleflower [Desmanthus virgatus var. depressus (Humbolt and Bonpland ex Willd.) Turner] seeds. Our objectives were to determine: (1) the effects of temperature on germination of scarified and untreated seeds in the light and dark and (2) the efficacy of various presowing treatments in increasing germination. Scarified (nicked with a razor blade) and untreated seeds were germinated at 5-15, 10-20, 15-25, 20-30, 25-35, and 30-40 C (12 hours - 12 hours) in the dark or with light during the warmer temperature. Effects of scarification with $17 \mathrm{M} \mathrm{H}_{2} \mathrm{SO}_{4}$, hot $\left(80^{\circ} \mathrm{C}\right)$ water, 0.7 mol liter $^{-1}$ $\mathrm{NaOCl}, 2.9$ mol liter $^{-1} \mathrm{H}_{2} \mathrm{O}_{2}$, and nicking with a razor blade on germination were compared. Maximum germination of untreated seeds was only $6 \%$. Germination of scarified seeds exceeded $90 \%$ at 15-25 $\mathrm{C}$ and higher temperatures. Light did not affect germination at optimal temperatures for germination. Nicking seeds with a razor blade, soaking 40 minutes in $17 \mathrm{M} \mathrm{H}_{2} \mathrm{SO}_{4}$, and soaking 25 minutes in hot $\left(80^{\circ} \mathrm{C}\right)$ water resulted in 91,88 , and $78 \%$ germination, respectively, compared to $3 \%$ for controls. Our results indicated that, for best germination, seeds should be soaked $\mathbf{4 0}$ minutes in $17 \mathrm{M} \mathrm{H}_{2} \mathrm{SO}_{4}$ or nicked with a razor and planted when mean minimum-maximum soil temperatures exceed 15-25 $\mathrm{C}$.
\end{abstract}

Key Words: seed dormancy, Desmanthus virgatus var. depressus, range seeding, presowing seed treatments

Prostrate bundleflower [Desmanthus virgatus var. depressus (Humbolt and Bonpland ex Willd.) Turner] ranges from the Rio Grande Plains north to central Texas and west to New Mexico (Vines 1960). The native legume is eaten by white-tailed deer (Odocoileus virginianus Raf.) (Drawe 1968) and its seeds are consumed by bobwhites (Colinus virginianus L.) (Wood et al. 1986), The plant has been evaluated by the USDA Soil Conservation Service (SCS) at Knox City, Texas, for use in range seeding and erosion control (Richard Heizer, State Plant Materials Specialist, USDA-SCS, pers. commun.).

The hard coat of Desmanthus seeds restricts germination. Lating (1961) reported that germination of Illinois bundleflower [ $D$. illinoensis (Michx.) MacM. ex Robins. and Fern.] was increased by soaking seeds for 10 minutes in concentrated sulfuric acid $\left(\mathrm{H}_{2} \mathrm{SO}_{4}\right)$ and by clipping seeds at the end opposite the micropyle with a knife. Haferkamp et al. (1984) found that velvet bundleflower ( $D$. velutinus Scheele) germination was increased by either cutting the seed coat with a razor, immersion of seeds in hot $\left(80^{\circ} \mathrm{C}\right)$

\footnotetext{
Authors are associate professor, College of Agriculture and Home Economics, Texas A\&I University, Kingsville 78363; and graduate research assistant, Caesar Kleberg Wildlife Research Institute. Texas A\&I University. Kingsville $\mathbf{7 8 3 6 3 .}$

Research was funded by the Caesar Kleberg Foundation for Wildlife Conservation Authors thank Dr. Bingham for assistance in statistical analysis and manuscript review.

Manuscript accepted 7 August 1986.
}

water for 3 minutes, or soaking seeds for 17 minutes in concentrated $\mathrm{H}_{2} \mathrm{SO}_{4}$. Our objectives were to determine: (1) the effects of 6 alternating temperature regimes on germination of scarified and untreated seeds in the light and dark and (2) the efficacy of various presowing treatments in increasing germination of prostrate bundleflower.

\section{Methods}

Seeds of accession 436898 prostrate bundleflower were obtained from the USDA-SCS Plant Materials Center at Knox City, Texas, and were stored in a cloth bag at $15^{\circ} \mathrm{C}$ and $40 \%$ relative humidity. They were 3 years old when used in experiments.

Seeds were germinated in blotter paper underlain by a layer of creped cellulose placed in 13.0 by 13.5 by $3.5-\mathrm{cm}$ plastic boxes with tightly fitting lids. The substratum was moistened with $100 \mathrm{ml}$ of tap water and remoistened when necessary. Seeds were treated with thiram [bis (dimethylthiocarbamoyl) disulfide] to minimize fungal growth.

Experiments were conducted with 4 boxes of 100 seeds each per treatment. Plastic boxes were arranged in controlled environment chambers in a randomized complete-block design. Each experiment was conducted twice except when otherwise stated. Data for the 2 experiments were combined for analysis and values reported in the text are the means of the experiments.

Prostrate bundleflower seeds were considered germinated when at least 1 cotyledon was exposed and radicles were $5 \mathrm{~mm}$ or greater in length (Kissock and Haferkamp 1983). Seedlings not meeting these requirements at the end of an experiment were considered abnormal. Counts were made daily for 28 days in temperature experiments and 14 days in presowing-treatment experiments. Germination rate index (GRI) was calculated as the sum of the quotients of the number of seeds germinated divided by the number of days for germination (Maguire 1962). Corrected germination rate index (CGRI) was obtained by dividing GRI by the final germination percentage and multiplying by 100 (Evetts and Burnside 1972).

\section{Temperature, Light, and Scarification}

Effects of temperature, light, and scarification on germination were determined by germinating scarified and untreated seeds at alternating temperatures of 5-15, 10-20, 15-25, 20-30, 25-35, and $30-40^{\circ} \mathrm{C}$ ( 12 hours -12 hours) in the dark or with light during the warmer temperatures. Seeds were scarified by nicking the distal end with a razor blade (Kissock and Haferkamp 1983, Haferkamp et al. 1984). For the light treatment, cool-white fluorescent light with an average photosynthetic photon flux density of $24 \mu \mathrm{mol}$ $\mathrm{m}^{-2} \mathrm{~s}^{-1}$ was provided. To maintain constant darkness, plastic boxes were wrapped in 3 layers of aluminum foil. A green light was used for counts. 
Table 1. Effects of 6 alternating (12 hours-12 hours) temperatures $(C)$, light (12 hours dally), and scartifeation (aicked with a razor blade) on percentage mean germination and etandard deviations, corrected germination rate index (CGRI), and percent abnorinal seedlinges of prostrate bundleflower'.

\begin{tabular}{|c|c|c|c|c|c|c|}
\hline \multirow[b]{2}{*}{ Seed treatments } & \multicolumn{6}{|c|}{ Temperature } \\
\hline & $5-15$ & $10-20$ & $15-25$ & $20-30$ & $25-35$ & $30-40$ \\
\hline \multicolumn{7}{|c|}{$\begin{array}{l}\text { Percent germination } \\
\text { Light }\end{array}$} \\
\hline $\begin{array}{l}\text { Scarified } \\
\text { Unt reated }\end{array}$ & $\begin{array}{l}3(1.8) \\
0\end{array}$ & $\begin{array}{r}67(14.8) \\
2(0.8)\end{array}$ & $\begin{array}{r}94(3.4) \\
4(2.4)\end{array}$ & $\begin{array}{r}95(1.8) \\
6(2.6)\end{array}$ & $\begin{array}{r}96(2.4) \\
5(1.5)\end{array}$ & $\begin{array}{r}92(2.4) \\
6(2.9)\end{array}$ \\
\hline Dark & & & & & & \\
\hline $\begin{array}{l}\text { Scarified } \\
\text { Untreated }\end{array}$ & $\begin{array}{l}18(11.3) \\
0\end{array}$ & $\begin{array}{r}81(6.6) \\
2(2.1)\end{array}$ & $\begin{array}{r}91(5.0) \\
4(2.3)\end{array}$ & $\begin{array}{r}95(1.9) \\
5(1.2)\end{array}$ & $\begin{array}{r}93(3.0) \\
5(1.6)\end{array}$ & $\begin{array}{r}93(4.0) \\
4(2.3)\end{array}$ \\
\hline \multicolumn{7}{|l|}{ CGRI } \\
\hline $\begin{array}{l}\text { Light } \\
\text { Scarified } \\
\text { Untreated }\end{array}$ & $\begin{array}{l}5(2.4) \\
0\end{array}$ & 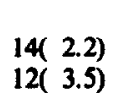 & $\begin{array}{l}30(1.3) \\
18(10.2)\end{array}$ & $\begin{array}{l}53(6.0) \\
29(10.6)\end{array}$ & $\begin{array}{l}50(1.0) \\
26(3.5)\end{array}$ & $\begin{array}{l}64(11.7) \\
36(14.4)\end{array}$ \\
\hline $\begin{array}{l}\text { Dark } \\
\text { Scarified } \\
\text { Untreated }\end{array}$ & $\begin{array}{l}6(1.0) \\
0\end{array}$ & $\begin{array}{l}17(2.1) \\
10(3.1)\end{array}$ & $\begin{array}{l}27(1.1) \\
14(4.3)\end{array}$ & $\begin{array}{l}50(15.3) \\
25(5.8)\end{array}$ & $\begin{array}{l}38(4.1) \\
26(11.9)\end{array}$ & $\begin{array}{l}59(10.5) \\
20(15.1)\end{array}$ \\
\hline \multicolumn{7}{|c|}{$\begin{array}{l}\text { Percent abnormal seedlings } \\
\text { Light }\end{array}$} \\
\hline $\begin{array}{l}\text { Scarified } \\
\text { Untreated } \\
\text { Dark }\end{array}$ & $\begin{array}{l}16(11.1) \\
<1(0.7)\end{array}$ & $\begin{array}{l}5(3.0) \\
<1(0.5)\end{array}$ & $\begin{array}{c}1(0.6) \\
<1(0.5)\end{array}$ & $\begin{array}{l}1(0.8) \\
<1(0.5)\end{array}$ & $\begin{array}{c}1(0.7) \\
<1(0.4)\end{array}$ & $\begin{array}{r}1(1.2) \\
<1(0.4)\end{array}$ \\
\hline $\begin{array}{l}\text { Scarified } \\
\text { Untreated }\end{array}$ & $\begin{array}{c}23(8.8) \\
0\end{array}$ & $\begin{array}{l}3(1.6) \\
1(0.7)\end{array}$ & $\begin{array}{r}3(1.4) \\
<1(0.5)\end{array}$ & $\begin{array}{l}1(0.7) \\
l(0.8)\end{array}$ & $\begin{array}{l}1(0.8) \\
1(1.1)\end{array}$ & $\begin{array}{l}\text { I(1.0) } \\
\text { I( } 1.0)\end{array}$ \\
\hline
\end{tabular}

IValues are means and standard deviations (in parentheses ), $n=8$.

Response curve analysis was used to determine the relationship between temperature and germination (Snedecor and Cochran 1967). Analysis of variance was used to determine if significant differences existed between light and scarification treatment means within each temperature. An arcsine transformation was used on percent germination and abnormal seedling data for analysis.

\section{Presowing Treatments}

Seeds were: (1) soaked $0,20,40,60$, and 80 minutes in concentrated (17 M) sulfuric acid ( $\mathrm{H}_{2} \mathrm{SO}_{4}$ ) (Young et al. 1981); (2) soaked $20,40,60$, and 80 minutes in hot water $\left(80^{\circ} \mathrm{C}\right.$ ) (Kissock and Haferkamp 1983, Haferkamp et al. 1984); (3) soaked 0, 15, 30, 45, and 60 minutes in 0.7 mol liter $^{-1}$ sodium hypochlorite ( $\left.\mathrm{NaOCl}\right),(4)$ nicked through the coat with a razor blade (Kissock and Haferkamp 1983, Haferkamp et al. 1984); and (5) soaked 0, 15, 30, 45, and 60 minutes in 2.9 mol liter ${ }^{-1}$ hydrogen peroxide $\left(\mathrm{H}_{2} \mathrm{O}_{2}\right)$ (Stidham et al. 1980). Seeds were rinsed 5 minutes with tap water after soaking. These experiments were conducted once with 4 replications of 100 seeds per box.

Response curve analysis was used to predict the optimum level of each presowing treatment. The optimum level of each treatment was then compared in a final experiment to determine the presowing treatment most effective in enhancing germination.

Data from the final experiment were analyzed by analysis of variance (Snedecor and Cochran 1967). Tukey's test was used at the $\mathbf{0 . 0 5}$ level to identify significantly different means when significant $F$ values were found (Kleinbaum and Kupper 1978). An arcsine transformation was used on percent germination and abnormal seedling data for analysis.

\section{Results}

\section{Temperature, Light, and Scarification}

Scarified and untreated seeds exhibited a quadratic response to temperature for percent germination in the light and in the dark (Tables 1 and 2). Germination of scarified seeds exceeded $90 \%$ at $15-25^{\circ} \mathrm{C}$ and higher temperatures. Maximum germination of untreated seeds was only $6 \%$.

CGRI of scarified and untreated seeds increased with increasing temperature in the light and dark (Tables 1 and 2). Maximum CGRI of scarified seeds was at $30-40^{\circ} \mathrm{C}$. CGRI was 13 times
Table 2. P- and $\mathbf{R}^{2}$ values for response curve analyses of the relationship between percent germinntion, corrected germination rate index (CGRI), and percent abnormal seedlings and temperature for prostrate bundlenower. $R^{2}$ values are for the quadratic model when it was aignificant $(P<0.05)$; otherwise values are for the linear model.

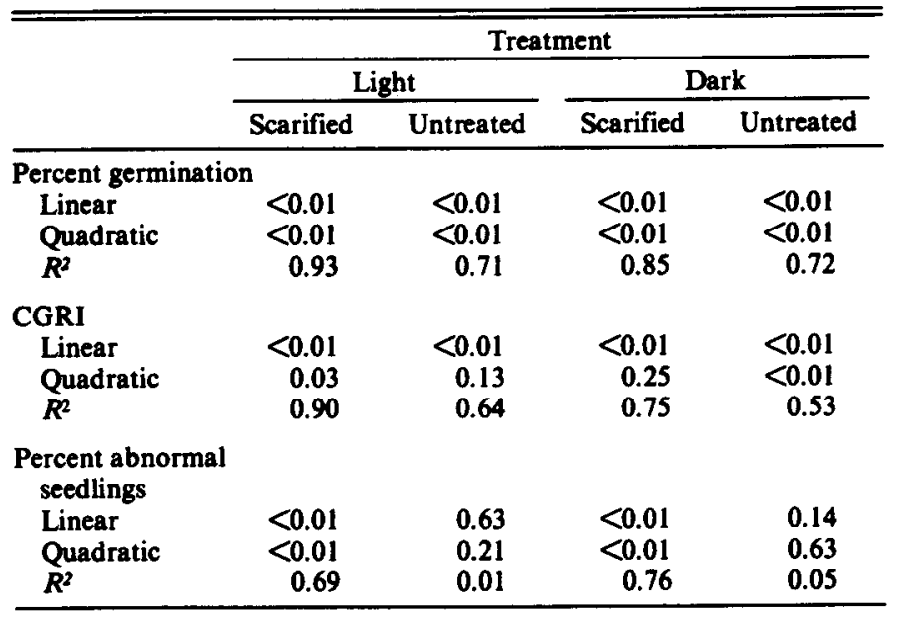

'Data for percent germination and percent abnormal seedlings were arcsine transformed.

higher at $30-40^{\circ} \mathrm{C}$ than at $5-15^{\circ} \mathrm{C}$ for scarified seeds in the light.

Percent germination was similar $(P>0.05)$ in the light and dark at $15-25^{\circ} \mathrm{C}$ and warmer temperatures (Tables 1 and 3). The light $X$ scarification interaction was significant $(P<0.01)$ at $5-15$ and $10-20^{\circ} \mathrm{C}$. At these temperatures, percent germination of scarified seeds was higher in the dark than light, whereas germination of untreated seeds was similar. For CGRI, the light $X$ scarification interaction was significant $(P<0.05)$ only at $10-20^{\circ} \mathrm{C}$. CGRI of scarified seeds was higher in the dark than light, while that of untreated seeds was higher in the light. At other temperatures CGRI was similar $(P>0.05)$ in the light and dark except at $30-40^{\circ}$ $C$ where it was lower in the dark.

Percent germination and CGRI of scarified seeds exceeded $(P<0.01)$ that of untreated seeds under all temperature and light conditions (Tables 1 and 3). Scarified seeds exhibited 13-41 times higher percent germination than untreated seeds. At temperatures 
Table 3. P- values for the analysis of variance of the effects of lifht (12 hours dally) and scarification (nicked with a razor blade) on percent germination, corrected germination rate index (CRRI), and percent abnormal seedlings of prostrate bundleflower for each temperature $\left(^{\circ} \mathrm{C}\right)^{1}$.

\begin{tabular}{|c|c|c|c|c|c|c|}
\hline \multirow[b]{2}{*}{ Seed treatment } & \multicolumn{6}{|c|}{ Temperature } \\
\hline & $5-15$ & $10-20$ & $15-25$ & $20-30$ & $25-35$ & $30-40$ \\
\hline $\begin{array}{l}\text { Percent germinatior } \\
\text { Light (L) } \\
\text { Scarification (S) } \\
\text { LXS }\end{array}$ & $\begin{array}{l}<0.01 \\
<0.01 \\
<0.01\end{array}$ & $\begin{array}{l}<0.01 \\
<0.01 \\
<0.01\end{array}$ & $\begin{array}{r}0.48 \\
<0.01 \\
0.26\end{array}$ & $\begin{array}{r}0.62 \\
<0.01 \\
0.51\end{array}$ & $\begin{array}{r}0.36 \\
<0.01 \\
0.37\end{array}$ & $\begin{array}{r}0.88 \\
<0.01 \\
0.23\end{array}$ \\
\hline $\begin{array}{l}\text { CGRI } \\
\text { Light (L) } \\
\text { Scarification (S) } \\
\text { LXS }\end{array}$ & $\begin{array}{r}0.21 \\
<0.01 \\
0.21\end{array}$ & $\begin{array}{r}0.65 \\
<0.01 \\
0.03\end{array}$ & $\begin{array}{r}0.11 \\
<0.01 \\
0.71\end{array}$ & $\begin{array}{r}0.20 \\
<0.01 \\
0.94\end{array}$ & $\begin{array}{r}0.06 \\
<0.01 \\
0.08\end{array}$ & $\begin{array}{r}0.03 \\
<0.01 \\
0.18\end{array}$ \\
\hline $\begin{array}{l}\text { Percent abnormal se } \\
\text { Light (L) } \\
\text { Scarification (S) } \\
\text { LXS }\end{array}$ & $\begin{array}{r}0.19 \\
<0.01 \\
0.07\end{array}$ & $\begin{array}{r}0.71 \\
<0.01 \\
<0.01\end{array}$ & $\begin{array}{r}0.11 \\
<0.01 \\
0.03\end{array}$ & $\begin{array}{l}1.00 \\
0.12 \\
0.78\end{array}$ & $\begin{array}{l}0.08 \\
0.03 \\
0.97\end{array}$ & $\begin{array}{l}0.07 \\
0.02 \\
0.58\end{array}$ \\
\hline
\end{tabular}

${ }^{1}$ Data for percent germination and percent abnormal seedlings were arcsine transformed.

above $15-25^{\circ} \mathrm{C}$, germination of scarified seeds was 1.5 to 3 times more rapid than that of untreated seeds.

Scarification increased $(P<0.05)$ the percent abnormal seedlings at all temperatures except $20-30^{\circ} \mathrm{C}$ (Tables 1 and 3 ). For scarified seeds, the percentage abnormal seedlings was highest at lower temperatures (Tables 1 and 2). Averaged across light treatments, there were 20 times more abnormal seedlings at $5-15^{\circ} \mathrm{C}$ than at $20-30^{\circ} \mathrm{C}$. Cotyledons extended through the nicked portion of seeds at $5-15^{\circ} \mathrm{C}$, but radicles did not reach $5 \mathrm{~mm}$ in length. Poor radicle development probably resulted because seedling vigor was low at this temperature. For untreated seeds, there was no significant $(P>0.05)$ relationship between percent abnormal seedlings and temperature. Percent abnormal seedlings did not differ significantly $(P>0.05)$ between light and dark (Tables 1 and 3 ).

\section{Presowing Treatments}

Prostrate bundleflower germination was not increased by soaking seeds in $0.7 \mathrm{~mol} \mathrm{liter}^{-1} \mathrm{NaOCl}$ and $2.9 \mathrm{~mol} \mathrm{liter}^{-1} \mathrm{H}_{2} \mathrm{O}_{2}$ (data not shown). Soaking seeds in hot $\left(80^{\circ} \mathrm{C}\right)$ water for $0,20,40,60$, and 80 minutes resulted in $3,87,75,17$, and $1 \%$ germination, respectively, $\left(\mathrm{y}=2.450+8.117 \mathrm{x}-0.217 \mathrm{x}^{2}+0.001 \mathrm{x}^{3}, R^{2}=0.96, P<0.01\right)$. Soaking seeds in $17 \mathrm{M} \mathrm{H}_{2} \mathrm{SO}_{4}$ for $0,20,40,60$, and 80 minutes resulted in 3, $98,99,95$, and $90 \%$ germination, respectively $(y=4.496+7.054 x-$ $0.151 \mathrm{x}^{2}+0.001 \mathrm{x}^{3}, R^{2}=0.98, P<0.01$ ). Predicted optimum duration of soaking for the hot water and $\mathrm{H}_{2} \mathrm{SO}_{4}$ treatments was 25 and 40 minutes, respectively.

Table 4. Effects of soaking in hot $\left(80^{\circ} \mathrm{C}\right)$ water for 25 minutes, soaking in $17 \mathrm{MH}_{2} \mathrm{SO}_{4}$ for 40 minutes, and nicking with a razor blade on germination of prostrate bundleflower seeds at $20-30^{\circ} \mathrm{C}(12$ hours with darkness - 12 hours with light).

\begin{tabular}{lccc}
\hline \hline Treatment & $\begin{array}{c}\text { Percent } \\
\text { germination }\end{array}$ & CGRI & $\begin{array}{c}\text { Percent abnormal } \\
\text { seedlings }\end{array}$ \\
\hline Control & $3 \mathrm{a}$ & $31 \mathrm{a}$ & $0 \mathrm{a}$ \\
Hot water & $78 \mathrm{~b}$ & $42 \mathrm{~b}$ & $1 \mathrm{ab}$ \\
$\mathrm{H}_{2} \mathrm{SO}_{4}$ & $88 \mathrm{bc}$ & $46 \mathrm{~b}$ & $4 \mathrm{~b}$ \\
Nicked & $91 \mathrm{c}$ & $41 \mathrm{~b}$ & $1 \mathrm{a}$ \\
\hline
\end{tabular}

'Values are means and standard deviations (in parentheses), $n=8$. Means in a column followed by the same letter are not significantly different at the 0.05 level according to Tukey's test.

Germination of seeds soaked 25 minutes in hot water and 40 minutes in $\mathrm{H}_{2} \mathrm{SO}_{4}$ was compared to that of seeds nicked with a razor and untreated in a final experiment. Nicking and soaking seeds in $\mathrm{H}_{2} \mathrm{SO}_{4}$ produced similar $(P>0.05$ ) results; however, percent germination of nicked seeds was higher $(P<0.05)$ than that of seeds soaked in hot water (Table 4). CGRI was similar among presowing treatments. Although $\mathrm{H}_{2} \mathrm{SO}_{4}$ scarification resulted in a higher percentage of abnormal seedlings than other treatments, the number was low.

\section{Discussion}

May, June, and September are peak rainfall months in south Texas (Gould 1975). Planting before peak rainfall periods should aid in establishment of prostrate bundleflower and temperatures during these months should be within the optimum range for germination.

Planting scarified seeds when soil temperature are below 10-20 C may result in considerable abnormal germination. Planting under these conditions should be avoided because the quantity of viable seed will be lower when conditions become more favorable for germination.

Optimal temperatures for prostrate bundleflower germination are apparently higher than those for Illinois bundleflower. Townsend and McGinnies (1972) found that germination of Illinois bundleflower was $93 \%$ at $5-20^{\circ} \mathrm{C}(12$ hours -12 hours $)$ but was less than $35 \%$ at $15-25$ and $20-35^{\circ} \mathrm{C}$. Conversely, germination of velvet bundleflower was much higher at $10-20,15-25$, and $20-30^{\circ}$ $\mathrm{C}$ than at $5-15^{\circ} \mathrm{C}$ (Haferkamp et al. 1984).

Methods effective in increasing germination of other Desmanthus species (nicking seeds, soaking in $\mathrm{H}_{2} \mathrm{SO}_{4}$, and soaking in hot water) also increased germination of prostrate bundleflower. Results indicated that nicking the seeds and soaking in $17 \mathrm{M}$ $\mathrm{H}_{2} \mathrm{SO}_{4}$ are the most effective treatments. For large lots of seeds, scarifying with $\mathrm{H}_{2} \mathrm{SO}_{4}$ would be more practical than nicking.

\section{Literature Cited}

Drawe, D.L. 1968. Mid-summer diet of deer on the Welder Wldlife Refuge. J. Range Manage. 21:164-166.

Evetts, L.L., and O.C. Burnaide. 1972. Germination and seedling development of common milkweed and other species. Weed Sci. 20:371-378.

Gould, F.w. 1975. Texas plants: a checklist and ecological summary. Texas Agr. Exp. Sta. MP/585 (Rev.). Texas A\&M Univ., College Station, Texas.

Haferkamp, M.R., D.C. Kiasock, and R.D. Webster. 1984. Impact of presowing seed treatments, temperature, and seed coats on germination of velvet bundleflower. J. Range Manage. 37:185-188.

Kissock, D.C., and M.R. Haferkamp. 1983. Presowing seed treatment and temperature effects on germination of Engelmania pinnatifida and Indigofora miniata var. leptosepala. J. Range Manage. 36:94-97.

KJeinbaum, D.G., and L.L. Kupper. 1978. Applied regression analysis and other multivariable methods. Duxbury Press, North Scituate, Mass.

Lating, J. 1961. The biology of Desmanthus illinoensis. Ecology 42:487-493.

Maguire, J.D. 1962. Speed of germination-aid in selection and evaluation for seedling emergence and vigor. Crop Sci. 2:176-177. 
Snedecor, G.W., and W.G. Cochran. 1967. Statistical methods, 6th edition. lowa State University Press, Ames, Iowa.

Stidham, N.D., R.M. Ahring, J. Powell, and P.L. Claypool. 1980. Chemical scarification, moist prechilling, and thiourea effects on germination of 18 shrub species. J. Range Manage. 33:115-118.

Townsend, C.E., and W.J. McGinnies. 1972. Temperature requirements for seed germination of several forage legumes. Agron. J. 64:809-812.

Vines, R.A. 1960. Trees, shrubs, and woody vines of the Southwest. Univ. of Texas Press, Austin.
Wood, K.N., F.S. Guthery, and N.E. Koerth. 1986. Spring-summer nutrition and condition of northern bobwhites in South Texas. J. Wildl. Manage. 50:84-88.

Young, J.A., R.A. Evans, B.L. Kay, R.E. Owen, and J. Budy. 1981. Collecting, processing, and germinating seeds of western wildland plants. USDA-SEA ARM-W-3. Agr. Res. (Western Region), Sci. and Educ. Admin., USDA, Oakland, Calif. 